\title{
MAJAS PERSONIFIKASI DAN SIMILE DALAM ANTOLOGI PUISI PEREMPUAN LAUT KARYA SEPULUH PEREMPUAN PENYAIR MADURA
}

\author{
M. Shoim Anwar, Sri Budi Astuti \\ Program Studi Pendidikan Bahasa Indonesia, Fakultas Ilmu Sosial dan \\ Humaniora Universitas PGRI Adi Buana Surabaya \\ shoimanwar@unipasby.ac.id
}

\begin{abstract}
ABSTRAK
Sastra adalah seni bahasa. Bahasa diperlukan secara mutlak oleh penyair untuk menuangkan ide, dirangkai secara estetis sehingga menimbulkan efek keindahan. Dalam konteks inilah majas atau gaya bahasa dihadirkan dalam puisi, seperti yang dilakukan oleh sepuluh perempuan penyair Madura melalui antologi puisi Perempuan Laut (2017). Puisi-puisi yang ada di dalam antologi tersebut adalah karya Weni Suryandari, Maftuhah Jakfar, Nok Ir, Juwairiyah Mawardy, Linda Autaharu, Tika Suhartatik, Benazir Nafilah, Nurul Ilmi Elbana, Nay Juireng Dyah Jatiningrat, serta Salama Ilmie. Antologi puisi Perempuan Laut di atas diteliti dengan tujuan untuk menginterpretasi, menganalisis, dan mendeskripsikan penggunaan majas pesonifikasi dan simile/asosiasi di dalamnya. Penelitian ini menggunakan pendekatan kualitatif. Sumber datanya adalah puisi-puisi yang terdapat dalam antologi tersebut, dikumpulkan melalui kepustakaan, serta dianalisis dengan teknis dialogis antara teks dan konteks. Hasil penelitian menunjukkan bahwa majas personifikasi dan simile/asosiasi terdapat dalam antologi puisi Perempuan Laut. Semua penyair pada antologi itu menggunakan majas personifikasi dan simile dengan kadar penggunaan yang berbeda. Tidak semua puisi menggunakan majas tersebut, namun dipergunakan pada sebagian saja.
\end{abstract}

Kata Kunci: puisi, majas, pesonifikasi, simile

\section{PENDAHULUAN}

Puisi adalah karya sastra yang tercipta secara imajinatif. Meski begitu, kadar imajinatifnya tidak bersifat mutlak. Puisi dapat pula dihasilkan melalui peristiwa nyata yang telah diolah oleh penyair dengan dipadukan berbagai pengalaman hidup, baik dari penyair maupun orang lain. Secara umum, puisi dapat ditulis berdasarkan pengalaman atau kehidupan diri sendiri, orang lain, bahan bacaan, media informasi, atau perpaduan dari hal-hal tersebut yang dirangkai dengan imajinasi.

Bahasa merupakan media yang secara mutlak harus terdapat dalam puisi. Pusi, atau karya sastra pada umumnya, adalah karya seni yang menggunakan media bahasa. Bahasa adalah piranti yang dipermainkan oleh penyair untuk menghasilkan keindahan tertentu. Bahasa dalam puisi memiliki ciri yang khas, terutama terkait pilihan kata atau diksi yang memiliki makna konotatif. Dalam konteks pemakaian bahasa inilah keberadaan majas atau gaya bahasa (style) menjadi sangat penting. Majas yang dipakai oleh penyair, selain isi, akan menjadi ciri yang mempribadi bagi penciptanya. Kadar kreativitas seorang penyair sangat 
ditentukan oleh majas yang dipakai sehingga karya itu dapat dibedakan dengan karya penyair lainnya. Sumardjo (1986:127) menjelaskan bahwa majas atau gaya bahasa adalah cara menggunakan bahasa agar daya ungkap atau daya tarik atau sekaligus kedua-duanya bertambah.

Pemakaian majas dalam puisi dapat diketahui lebih cepat oleh pembaca karena puisi secara umum bentuknya lebih pendek dibandingkan dengan prosa. Majas terkait dengan bentuk yang secara kasat mata lebih awal dapat dilihat. Bila diibaratkan pertandingan, pertarungan antarpenyair ditentukan oleh majas yang dipakai dan ditemukan secara personal.

Majas atau gaya bahasa dalam puisi menyangkut pemakaian bahasa secara luas. Majas itu dapat dikaitkan dengan irama dan rima, namun tidak menghilangkan makna dalam setiap katanya. Majas dalam puisi juga terkait cocok tidaknya pemakaian kata, frasa atau klausa. Pemilihan kata, frasa atau klausa mencakup bentuk kata secara keseluruhan, bahkan nada yang tersirat di balik sebuah bentuk kata termasuk pula gaya bahasa (Keraf, 2009:112). Majas adalah setiap pemilihan kata yang mencakup keseluruhan bentuk kata, frasa atau klausa dan dipadukan dengan nada dalam puisi. Jumlah majas tentu banyak, tergantung pembagian dari sudut pandang tertentu. Agar tidak melebar, kajian terkait penggunaan majas dalam puisi dapat dibatasi pada majas tertentu.

Penggunaan majas simile (persamaan) dan personifikasi dalam puisi hendak dikaji dalam penelitian ini. Puisi-puisi yang dipilih adalah karya para perempuan penyair Madura, yaitu penyair yang secara kultural lahir atau dibesarkan di Pulau Madura. Warna etnis kemaduraan tampak meski para penyair itu ada yang berpindah ke tempat atau pulau lain sebagai konsekuensi kehidupan. Karya-karya mereka, sebagian, telah dibukukan dalam sebuah antologi bersama berjudul Perempuan Laut yang terbit tahun 2017. Antologi tersebut memuat puisi karya sepuluh orang perempuan penyair Madura.

Dari segi majas yang digunakan oleh sepuluh perempuan penyair Madura tentu sangat beragam., terkait berbagai macam hasil olahan daya imajinatif dan peristiwa yang telah dialami mereka..

Antologi Perempuan Laut diterbitkan oleh Forum Bias Sumenep. Pada kata pengantar, yang ditulis oleh Syaf Anton Wr, dijelaskan bahwa antologi ini memuat karya para penyair lintas generasi. Para penyair tersebut telah memberikan kontribusi dalam perkembangan karya sastra di tanah air Indonesia. Nama-nama seperti Weni Suryandari, Maftuhah Jakfar, dan Juwairiyah Mawardy merupakan penyair yang lebih senior dibandingkan tujuh nama lainnya, yaitu Nok Ir, Linda Autaharu, Tika Suhartatik, Benazir Nafilah, Nurul Ilmi Elbana, Nay Juireng Dyah Jatiningrat, serta Salama Ilmie.

Ada beberapa majas perbandingan yang menjadi ciri khas penulis dalam setiap karyanya dalam puisi antologi puisi Perempuan Laut, seperti Weni Suryandari menggunakan majas personifikasi, menggunakan kata-kata benda dan keadaan di sekitar untuk dijadikan materi dalam puisinya. Bait puisi "Perempuan Laut" melukiskan hal tersebut.

Debur ombak di batu karang, pecah seribu impian saat tanah darahku memenara dalam kabut kota sementara tubuhku adalah tempatmu menjaring kehidupan pantai yang meninggalkan kesedihan (PL, 2017:2) 
Maftuhah Jakfar memiliki ciri khas yang terkait spiritualisme dalam puisipuisinya. Dari sisi bentuk, majas personifikasi dan simile digunakan untuk menorehkan keindahan seperti pada contoh berikut.

Wahai Maulana

Rinai suara mulai memancar

Dari bulu serulingmu yang berpendar

Bergelora di tengah ruang hampa

Merambat pada udara

Seperti suara rindu yang magis

Di telinga rumpun bambu yang menangis

(PL, 2017:15)

Juwairiyah Mawardy juga menggunakan majas personifikasi dalam puisinya, karena menunjukan bahasa kiasan menggambarkan benda mati atau tidak bernyawa seolah-olah memiliki sifat kemanusiaan, seperti pada puisinya berjudul "Ombak Hidup" yang mempunyai arti lain, yaitu masalah dalam kehidupan.

"Kalau nanti ombak datang lagi

bermaksud bersenda gurau tentang tragedi

aku tak akan menyemburkan caci maki

atau penyesalan

karena ombak hanyalah sujud

mengikuti perintah ilahi

sebagaimana malaikat diciptakan

untuk sepenuhnya memuji

sekalipun dengan hemburan jampi-jampi

agar hidup tak sepenuhnya mimpi"

Linda Autaharu pun memiliki majas personifikasi, seperti dalam puisi yang berjudul "Tangga dan Gajah"

Tentu masih banyak majas personifikasi dan simile dalam antologi puisi ini. Maknanya dapat terkait dengan spiritual, peristiwa, pertemanan, dan permasalahan hidup. Tetapi, dalam penelitian ini hanya akan dibahas pemakaian majas personifikasi dan simile/asosiasi sebagai ciri yang menonjol. Tujuannya adalah untuk menginterpretasikan, menganalisis, dan mendeskripsikan pemakaian majas personifikasi dan simile/asosiasi dalam antologi puisi Perempuan Laut yang ditulis oleh sepuluh perempuan penyair Madura.

Penelitian terkait penggunaan majas atau gaya bahasa dalam puisi jumlahnya sangat banyak. Salah satu diantaranya dilakukan oleh Siti Nurhamidah (2019) yang meneliti gaya bahasa pada kumpulan puisi Perahu Kertas karya Sapardi Djoko Damono dan dihubungkan dengan pembelajaran di SMA.

Majas atau gaya bahasa adalah bagian dari kajian stilistika (Toolan, 1990; Ratna, 2016). Majas memiliki berbagai macam bentuk dan nama. Gorys Keraf (1986) membagi majas menjadi lima kelompok besar, yaitu berdasarkan segi bahasa dan nonbahasa, berdasarkan pilihan kata, berdasarkan nada, berdasarkan struktur kalimat, berdasarkan langsung dan tidaknya makna. Masing-masing kelompok majas tersebut dibagi lagi menjadi beberapa bagian sehingga jumlah keseluruhan mencapai puluhan. 
Kajian atau teori terkait puisi akan sangat panjang jika menelaah atau memberi contoh keberadaan majas dalam teks puisi. Suminto A. Sayuti (2008) dalam buku Berkenalan dengan Puisi memberi penekanan pemakaian majas kiasan: metafora-simile, metonimi-sinekdoki, personifikasi, dan simbol. Sedangkan Luxemburg dkk. (diterjemahkan dan adaptasi oleh Dick Hartoko, 1986) memberi penekanan pada majas kiasan yang mencakup: metafora dan perumpamaan; personifikasi, sinestesi; metonimia dan sinekdoke; pars pro toto, totem pro parte; lambang; pengungkapan tidak langsung, ironi.

Majas personifikasi adalah gaya bahasa yang memberi sifat atau perilaku benda mati/tidak bernyawa yang seakan dapat bertindak seperti manusia. Atau, bahasa kiasan yang menggambarkan benda-benda mati atau barang-barang yang tidak bernyawa seolah-olah memiliki sifat-sifat kemanusiaan (Keraf,1986:140). Personifikasi itu "memanusiakan" benda mati/tidak bernyawa. Contoh yang sangat umum dipakai adalah "Pohon nyiur itu melambai-lambai di pantai". Kata "melambai" pada awalnya hanya dipakai oleh manusia untuk memanggil/menyapa pihak lain. Pohon nyiur sebenarnya hanya dapat "bergerak" ketika ditiup angin. Contoh lain pemakain majas personifikasi adalah "Matahari mulai mengintip di ufuk timur", "Bintang-bintang itu berkedip di langit," dan masih banyak lagi.

Majas simile (ada yang menyamakan dengan majas asosiasi) adalah perbandingan yang bersiaf eksplisit, langsung menyatakan sesuatu sama dengan yang lain dengan menggunakan seperti, sebagai, bagaikan, laksana, tak ubahnya, dll. (Sayuti, 2008:196). Contohnya seperti kutipan puisi "Kampung" karya Subagyo Sastrowardoyo: "hidup ini negeri ini seperti di dalam kampung." Contoh lainnya, "Jantungku menderas bagai arus sungai seusai hujan".

\section{METODE PENELITIAN}

Penelitian ini menggunakan pendekatan kualitatif dan dituangkan secara deskriptif. Moleong (2014:4) memberi batasan pendekatan kualitatif adalah cara penelitian yang menghasilkan data deskriptif berupa kata-kata tertulis. Sumber datanya adalah antologi puisi Perempuan Laut (selanjutnya disingkat PL) yang memuat karya sepuluh perempuan penyair Madura, yaitu Weni Suryandari, Maftuhah Jakfar, Nok Ir, Juwairiyah Mawardy, Linda Autaharu, Tika Suhartatik, Benazir Nafilah, Nurul Ilmi Elbana, Nay Juireng Dyah Jatiningrat, serta Salama Ilmie. Antologi puisi tersebut diterbitkan oleh Forum Bias Sumenep, Madura, bekerja sama dengan BPR Syariah "Bakti Sumekar" pada tahun 2017.

Data penelitian diambil dari penggalan puisi-puisi para penyair tersebut yang menggunakan majas personifikasi dan simile.

Data penelitian dihimpun dari kepustakaan atau sumber-sumber tertulis sebagai bahan yang masih mentah (Sutopo, 2002:73). Pengumpulan data dan analisisnya dilakukan secara berjenjang mulai dari pembacaan karya puisi secara cermat dan berulang, menginterpretasi maknanya, memberi tanda bagian-bagian puisi yang mengandung majas personifikasi dan simile, mengelompokkan menjadi beberapa bagian, menganalisis katerkaitan antara bentuk/majas dan isi puisi, mendeskripsikan, serta menyimpulkan sebagai hasil penelitian.

\section{HASIL PENELITIAN DAN PEMBAHASAN}




\section{Majas dalam Puisi Karya Weni Suryandara}

Puisi-puisi Weni Suryandari ditempatkan pada urutan pertama dalam buku Perempuan Laut. Dari sisi usia, karena penempatan urutan tidak berdasarkan alfabetis, mungkin dia termasuk penyair yang lebih senior dibanding yang lain. Weni berasal dari keluarga besar Madura di Sumenep, tapi lahir di Kota Surabaya. Kultural Madura telah melekat padanya meski berpindah ke wilayah lain. Dia bayak menulis puisi dan prosa. Karyanya ikut dalam berbagai antologi.

Puisi-puisi Weni Suryandari banyak menggunakan majas personifikasi, yaitu gaya bahasa kiasan yang menggambarkan benda mati atau tidak bernyawa seolaholah memiliki sifat atau bertingkah laku seperti manusiaan. Benda mati atau sesuatu itu ditempatkan sebagai subjek/pelaku dari serangkaian tindakan. Majas ini digunakan untuk memberi kesan hidup pada sang pelaku.

Karya puisi pertama dalam buku antologi Perempuan Laut judulnya sama dengan judul buku. Itu berarti puisi ini dinilai memiliki relevansi dengan keseluruhan isi buku, atau terkait dengan kondisi alam dan sosiologis masyarakat Madura. Laut menjadi bagian penting dari kehidupan masyarakat Madura, baik secara simbolis sebagai perantau atau matapencaharian sebagai nelayan. Berikut kutipan puisi tersebut.

\section{Perempuan Laut}

Debur ombak di batu karang, pecah seribu impian

saat tanah darahku memenara dalam kabut kota

sementara tubuhku adalah tempatmu menjaring kehidupan

pantai yang meninggalkan kesedihan (PL, 2017:2)

Secara maknawi, majas pada kutipan di atas bergaya metafora karena makna perempuan laut dapat dikaitkan dengan keberadaan perempuan yang disetarakan dengan sifat-sifat laut, tempat mencari dan melanjutkan kehidupan. Majas dalam penggalan puisi di atas juga bergaya personifikasi, karena menggambarkan sebuah kesedihan dengan memakai benda-benda tidak bernyawa seperti batu karang dan tanah seolah memiliki sifat-sifat kemanusiaan, yaitu sedih. Sebuah kehidupan yang memiliki tujuan untuk menggapai impian harus melewati rintangan, yaitu ombak yang menerjang dan kerasnya batu karang. Di balik kesedihan juga pasti ada kebahagian, yakni impian yang tercapai.

Majas personifikasi juga terdapat dalam puisi "Pohon Perempuan" yang ditulis Weni Suryandari. Tampak sosok perempuan juga dikedepankan oleh penyair.

tempat segala sayap mengepak, mencipta angin engkau begitu kuat, kadang-kadang seperti albatross

mengangkasa bermil-mil, sehingga hinggap pada dahan terjauh

di lain waktu engkau serupa pohon oak, teduh dan kuat

lebih kekar dan belukar, lebih lebat dari akar

sarang-sarang burung tebal menganga rekah (PL, 2017:3)

Penggalan puisi di atas memunculkan tafsir perempuan yang diibaratkan seperti pohon serta pohon yang diibaratkan seperti perempuan. Majas yang dipakai adalah metafora karena berupa perumpamaan langsung yang simbolis. Munculnya kata "seperti albatross" dan "serupa pohon oak" juga mendakan puisi 
itu menggunakan majas simile atau asosiasi, yaitu perumpaan dengan menunjukkan persamaan sifat secara eksplisit dengan menggunakan kata-kata bantu "serupa" dan "seperti". Di sisi lain, terdapat majas personifikasi karena menggambarkan benda atau pohon yang memiliki sifat seorang seorang perempuan yaitu kuat, teduh, dan mengayomi.

Puisi di atas menyiratkan keberadaan perempuan yang kuat dan kekar dalam berbagai sisi,tapi juga mampu melindungi atau memberi keteduhan, pada anakanak khususnya. Perempuan juga mampu meraih keinginan yang tinggi.

\section{Panen Air mata}

Tunggulah hujan pudar dari bola mataku seajaib waktu yang melipat jarak dari kesenjangan

kini, masihkah sawah dan gelisah bertukar kisah sedang ibu bumi menelan air mata sendiri

(PL, 2017:4)

Gaya bahasa dalam penggalan puisi "Panen Air Mata" di atas merupakan gaya personifikasi, menggambarkan perasaan sedih dengan barang yang tidak bernyawa seperti hujan yang memiliki sifat seperti manusia. Majas tersebut tampak pada penggunaan "sawah dan gelisah bertukar kisah" dan "ibu bumi menelan air mata sendiri"

Pengunaan judul "Panen Air Mata" juga bersifat metaforik, yakni kesedihan yang sangat. Tampaknya masih terkait dengan perempuan karena ada metafor "ibu bumi" yang dikaitkan dengan perjalanan waktu atau pengalaman yang dilewati. Masa lalu dan masa kini dalam kenangan yang merajut kehidupan dapat melahirkan kesedihan.

Puisi karya Weni Suryandari yang menggunakan majas simile atau asosiasi juga tampak pada kutipan berikut.

\section{Mawar Gugur}

aku tak sanggup berkata, puisi terkunci

pada tatapan serupa kilat mata pisau

siap menghunjam kedalam dada.

berkawan hujan dan luka,

menderas dari bola mataku.(PL, 2017:6).

Majas dalam penggalan puisi di atas merupakan gaya simile atau asosiasi karena menunjukan persamaan perasaan dengan yang lain. Terdapat kata "serupa", menjelaskan perasaan sedih yang dituangkan dalam puisi serupa dengan tajamnya kilat mata pisau yang menusuk hati. Penggalan puisi di bawah ini yang langsung menyatakan sesuatu hal yang serupa dengan yang lain. Perhatikan penggunaan kata "seperti" untuk memberi perumpamaan dengan persamaan sifat.

\section{Menjemput Bintang}

Dasar laut bergeming menemani ikan-ikan berlarian sisiknya menyala cahaya perak seperti bulan purnama menjelang laut pasang, para kekasihnya merajuk memetik bintang dengan rangkaian janji untuk cinta (PL, 2017:7) 
Makna penggalan puisi tersebut tentang tatapan mata sepasang kekasih yang menyala atau bercahaya menyerupai kilauan sisik ikan di laut yang terkena pantulan sinar bulan purnama. Sepasang kekasih itu merangkai janji untuk saling mencintai.

\section{Rumah Lupa}

Kita berjalan di dua arah berbeda

seperti pengembara tersesat yang mencari

kesetiaan malam di lubuk-lubuk pagi hari

ini bukan sebuah mimpi buruk, menantang

nyali dalam berbagai peristiwa nyeri (PL, 2017:10)

Majas dalam penggalan puisi di atas adalah gaya simile. Hal itu tampak pada penempatan kata "seperti" di antara "Kita berjalan di dua arah berbeda" dengan "pengembara tersesat yang mencari". Puisi tersebut tentang orang-orang yang tengah kebingungan memilih tujuan atau jalan kehidupan karena terdapat di judulnya yaitu "Rumah Lupa"

\section{Majas dalam Puisi Karya Maftuhah \\ Jakfar}

Penyair perempuan dari Madura lainnya adalah Maftuhah Jakfar. Dia lahir dan besar di Sumenep. Kultur Madura tertanam amat kuat pada dirinya. Meski setelah menikah bermukim di luar Pulau Madura, Jakarta, kemaduraannya masih kental. Pada beberapa puisinya penyair ini lebih banyak menggunakan majas simile/asosiasi dan majas personifikasi .

\section{Mikraj Cinta V}

Bahwa seruling tak akan pernah bersuara indah

tanpa melalui pedih perpisahan

dengan rumpunnya yang menguning

seperti anggur yang digiling

sebelum menjadi minuman yang menyegarkan

\section{(PL, 2017:16)}

Gaya bahasa dalam penggalan puisi di atas merupakan gaya bahasa simile, karena menunjukkan kata seperti, menyatakan sesuatu hal yang sama dengan yang lain. Bait puisi itu berisi tentang mencapai keindahan atau kebahagiaan akan melalui berbagai proses yang sulit, bahkan menyakitkan, sama halnya dengan proses anggur yang digiling sebelum menjadi minuman yang menyegarkan.

Majas simile juga ditulis Maftuhah Jakfar dalam puisi "Nur Ala Nur" : "Bila Musa saja takluk di kaki Thursina / Dalam tajalli-Mum / Maka segala seumpama laron yang hancur tanpa abu" (TL, 2017:19. Pada penggalan puisi tersebut terdapat penggunaan kata "seumpama" sebagai ciri utamanya. Ada pula majas simile dalam puisi "Rindu Ilalang I" dengan ciri utama penggunaan kata "seperti".

Di lading jagung

Aku yang kecil

Berlarian seperti kupu-kupu

Bunga ilalang itu kau hadiahkan untukku 
(PL, 2017: 20).

Puisi Maftuhah Jakfar juga ada yang gunaklan majas personifikasi. Pada bait pertama puisi "Mikraj Cinta I" dia menulis majas tersdebut: "Permadani merah itu telah digelar / Persembahan mulia segera dimulai / Matahari akan menyanyikan lagu cinta / Dengan kata-katab tanpa suara" (PL, 2017:12). Perhatikan objek "matahari" yang . dilukiskan "akan menyanyikan lagu cinta" Matahari diberi sifat seperti manusia yang dapat menyanyi. Majas serupa ditampilkan Maftuhah dalam puisi "Mikraj Cinta III". Kali ini "cahaya" dan "udara" yang diberi sifat seperti manusia: "Gemerlap cahaya mengitari semesta / Udara bersuara dalam dalam ekstase jiwa / Dalam pecahan langit-langit doa" (PL, 2017:14).

Pada bait pertama puisi "Mikraj Cinta IV", Maftuhah kembali menampilkan majas personifikasi "rumpun bambu yang menagis" yang dipadakukan dengan majas simile pada baris sebelumnya dengan menampilkan kata "seperti". Perhatikan kutipannya.

\section{Wahai Maulana}

Rinai suara mulai memancar

Dari bulu serulingmu yang berpendar

Bergelora di tengah ruang hampa

Merambat pada udara

Seperti suara rindu yang magis

Di telinga rumpun bambu yang menangis

(PL, 2017:15)

Makna yang terkait spiritualisme sangat kuat pada puisi-puisi Maftuhah Jakfar. Penggunaan kata "mikraj" sebagai judul member penanda yang khas spiritualisme dalam Islam. Semua puisinya dalam kumpulan ini diarahkan ke spiritualisme, hubungan antara manusia sebagai hamba kepada Tuhan sebagai pencipta. Keberadaan manusia dalam kehidupan hingga kematian bergantung dan diserahkan sepenuhnya kepada Tuhan. Sebuah penyerahan dalam cinta yang tulus dan sejati.

\section{Majas dalam Puisi Karya Nok Ir}

Nok Ir nama aslinya adalah Hj.Khoiroh. Dia sebenarnya lahir di Demak, Jawa Tengah, tetapi perjalanan hidupnya berpuluh tahun dilakoni di Sumenep, Madura, sebagai seorang guru atau pendidik. Puisi-puisinya terkait Madura tidak diragukan lagi. Budaya Madura telah mewarnai karya-karyanya.

Secara bentuk, dalam kumpulan Perempuan Laut, puisi Nok Ir tidak banyak yang menggunakan majas perbandingan. Ciri umum puisinya langsung mengarah ke persoalan hidup yang dilakoni dari masa lalu ke masa kini. Salah satu puisi yang menggunakan majas personifikasi adalah "Selamat malam Sang Penyair" (bagian III)". Sang,

musim telah menyingsing

melipat jarak, melangkahi waktu

hingar dan riuh menjadi satu

mayapada semakin mempesona

ketika rembulan menyunting matahari

berbekal untaian reranting gering 


\section{berupa ingatan meruncing}

(PL, 2017:26).

Majas personifikasi pada kutipan puisi di atas terkait pelukisan pergantian waktu antara musim, bulan, dan matahari. Mungkin ini terkait waktu senja yang mengesankan keindahan. Musim, matahri, dan bulan dilukiskan berperilaku "melangkahi" dan "menyunting" seperti halnya manusia.

\section{Majas dalam Puisi Karya Juwariyah Mawardy}

Juwariyah Mawardy adalah perempuan penyair yang besar dan hidup di Madura, yaitu di Sumenep. Di samping menulis puisi, dia juga menulis cerita pendek dan esai. Profesi lain yang dijalani adalah sebagai pendidik.

Puisi-puisi Juwariyah Mawardy juga ada yang menggunakan majas personifikasi, kiasan yang menggambarkan benda mati atau tidak bernyawa seolah-olah memiliki sifat kemanusiaan. Pada salah satu puisinya dia memberi kesan perilaku pada ombak yang dapat "bersenda gurau", dan "sujud".

\section{Ombak Hidup}

kalau nanti ombak datang lagi

bermaksud bersenda gurau tentang tragedi

aku tak akan menyemburkan caci maki

atau penyesalan

karena ombak hanyalah sujud

mengikuti perintah ilahi

sebagaimana malaikat diciptakan

untuk sepenuhnya memuji

sekalipun dengan hamburan jampi-jampi

agar hidup tak sepenuhnya mimpi (PL, 2017:34)

Puisi tersebut berisi tentang seseorang (aku lirik) yang berusaha untuk ikhlas dan berserah, mungkin awalnya dirundung kesedihan karena tertimpa suatu masalah, si aku memilih pasarah untuk bersujud kepada Tuhan Sang Pencipta, dari sanalah dia menerima ujian, musibah, dan dari sanalah usaha ditempuh agar bisa melaluinya.

Juwariyah Mawardy juga menulis puisi antara lain menggunakan majas simile atau asosiasi. Berikut adalah puisi yang bergaya bahasa simile.

\section{Sajak Dari Kampung}

Lihat, kendaraan seperti panah dilepas busur

menabur diri di jalan beraspal ke alur-alur

hidup yang bersulur-sulur (PL, 2017:39)

Majas dalam penggalan puisi di atas merupakan simile atau persamaan, antara kendaraan yang melaju dengan anak panah yang dilepas dari busurnya. Pada sisi lain, dilukiskan keberadaan kendaraan di jalan itu seperti perjalanan hidup yang mengalir ke berbagai arah.

Majas simile pada puisi Juwariyah Mawardy pun tampak pada puisi "Wajahmu Adalah Pintu": pernah kubuka wajahmu sebagai pintu / berwarna biru, menjanjikan sesuatu / lantas kukunci; suatu kisah kasih merah muda". Puisi ini menggambarkan hubungan antarmanusia di masa muda. Semacam percintaan 
yang mengalami penduaan karena hadirnya orang lain: "tapi dia datang mengetuk pintu yang sama." Ada tiga sumbjek yang terlibat: -ku,-mu, dan dia.

\section{Majas dalam Puisi Karya Linda}

Autaharu

Linda Autaharu adalah perempuan penyair yang berdarah Madura, lahir di Surabaya, namun dibesarkan di Sumenep Madura. Nama aslinya adalah Halida Nurmayanti. Disamping sebagai penulis, Linda juga berprofesi sebagai pendidik.

Puisi Linda Autaharu yang menggunakan majas personifikasi antara lain berjudul "Tangga dan Gajah" .

Harus menyiapkan rumah yang besar untuk seekor gajah. Tidak boleh banyak rumah, bila itu kecil maka tiada guna bagi si gajah. Cukup satu dengan desain yang tak rumit agar gajah mampu bernafas lega. Selega nafas seseorang yang ketika di masa kecil memanjat kekukuhan menara-menara yang ada. (PL, 2017:42).

Majas dalam penggalan puisi di atas secara agak tersamar menggunakan majas personifikasi, karena mengkaitkan beberapa hal seperti tangga, gajah, dan rumah yang memiliki sifat-sifat manusia, tumbuh dan berkembang dalam perjalanan hidup. Secara tersirat terkandung makna ingin menempuh hidup secara ideal, meski tidak mewah, tidak mendua sehingga tercipta ketenangan.

Majas personifikasi lebih eksplisit terdapat pada puisi "Selamat Pagi: Anakku": Pagi yang menyelinap / tinggalkan kabut senantan / sesangku embun di meja makan / menghapus senak dalam ingatan." Majas yang sama terdapat pada puisi "Lelaki Berwajah Kemarin".

Kini kau cemas, memikirkan hari-hari adalah sama saja

dimana saat matahari memamerkan diri, cahaya lain tak akan mampu begitu terang

biarkan saja pagi dan malam memadu kisah, mengumpulkan jarum jam yang kelak dapat menusuk urat nadi siapa saja .

(PL, 2017:44)

Majas personifikasi pun tampak pada puisi "Tidurlah". Penyair melukiskan situasi antara gelap dan terang, ada subjek "kau/mu" yang dihimbau untuk tidur. Tidak terlalu jelas siapakah "kau/mu" yang dimaksud, seseorang atau sesuatu yang menyala itu sendiri.

Tidurlah kau dengan tenang,

Gelap tak kan membunuhmu tiba-tiba

hanya karena kau memadamkan dirimu

dengan diam-diam

(PL, 2017:48)

\section{Majas dalam Puisi Karya Tika Suhartatik}

Tika Suhartatik lahir dan besar di Pulau Madura. Aktif di dunia jurnalistik, di samping menjadi pendidik di Sumenep sabagai kota kelahirannya. Tidak hanya menulis puisi, dia juga menulis esai dan cerita pendek.

Majas personifikasi dalam puisi Tika Suhartatik antara lain terdapat pada puisi "Pilihan Janji Bersama Waktu" dan "Ada Tuhan Antara Kau dan Aku".

"aku dengar genderangmu berdendang tentang namaku / bersama bilis meringis dalam himpit rambutmu" itu adalah kutipan dari judul pertama. Ada 
"genderangmu berdendang" sebagai majas personifikasi. Majas yang sama ditampilkan lewat puisi kedua:

kini sungaisungai itu berhias teratai yang tak lagi berjuntai

padaoma bunganya

hidup serasa tanpa warna, tanpa rasa

(PL, 2017:56)

Sebuah lagi majas personifikasi dalam puisi Tika Suhartatik berjudul "Buku Puisi: Menyibak Dilema di Sebuah Negeri Tak Beratap." Puisi ini merupakan kritik yang cukup tajam pada dunia perpolitikan tanah air. Pembicraan tentang kampanye hingga perilaku para aktornya. "Negeri ini memang sudah kenyang dilema bersimbah angkara". Begitu Tika menuliskan situasi negara dengan majas personifikasinya. Kata "kenyang" dipakai untuk menjelaskan kondisi sering,berulang, atau dalam takaran yang berlebih seperti halmya manusia yang makan.

\section{Majas dalam Puisi Karya Benazir Nafilah}

Benazir Nafilah lahir dan besar di Madura. Dia aktif dalam berbagai kegiatan bersastra. Ikut dalam berbagai even yang memunculkan karyanya. Puisinya ikut dalam berbagai antologi bersama maupun terbit tersendiri.

"Dan kedatangan (dia-aku) / Telah menjadikan senja bunting dengan keemasan yang memerah / serupa matamu yang berlinang dusta", demikianlah Benazir menulis dengan majas personifikasi pada puisi "Akhirnya". Puisi yang menarasikan pertemuan dan perpisahan antarmanusia.

Secara berulang majas personifikasi juga dipakai Benazir pada puisi "Bertemu Puisi". Tampaknya puisi ini merupakan dunia kepenyairannya yang dilukiskan dalam puisi. Ada yang tak dapat dipisahkan antara puisi dan kehidupan, bahkan yang ada di sekitar, mungkin juga manusia, adalah puisi.

Karena yang menagis bersama hujan adalah puisi

Yang berdetak bersama jantung adalah puisi

Yang membawa kaki padamu adalah puisi

Aku menyukai puisi-puisiku; kamu!

(PL, 2017:69)

Pada puisi yang dikutip di atas juga terdapat majas simile atau asosiasi dengan kata "seperti"n sebagai kunci: "Aku menemukanmu / Aku menemukan puisi / Kau seperti hujan / Membasahi jantung ini . Majas yang sama digunakan secara berulang pada puisi "Kedua Mata Nabil, Sareyangku"

Tangismu serupa debur ombak yang menghempas jantungku, nak

Ketika jauh darimu sesak kurasa

Sebab kau adalah udara kedua yang dicipta Tuhan untuk memenuhi rongga jantungku

Kupahat wajahmu yang bulat sempurna seperti telur yang kamu suka

Kususun memory bersamamu seperti puzzle yang sering kita mainkan bersama

Gigimu menyembul tak teratur seperti nada suaramu yang tinggi rendah

(PL, 2017:65)

Majas simile juga digunakan Bernazir Nafilah dalam puisi "Telur Dadar": kau berucap telur ini seperti kita "kau kuningnya dan aku putihnya". Di samping terkait dunia kepenyairannya, puisi-puisi Benazir juga berbicara tentang anak yang sangat dicintai, seiring dengan adanya hubungan yang retak atau putus 
dengan pihak lain yang disebutnya sebagai "kau", mungkin perpisahan atau kematian. Permasalahan ini juga ditulis dalam puisi "Akhirnya" yang juga bermajas simile.

\section{Akhirnya}

Akhirnya aku harus mengerti

bahwa pertemuan dan perpisahan adalah alasan waktu

dan aku serupa bunga kuncup yang tiba-tiba berkembang lalu

seketika gugur tanpa sebab (PL, 2017:64).

\section{Majas dalam Puisi Karya Nurul Ilmi Elbana}

Nurul Ilmi Elbana adalah perempuan penyair dari Madura yang pernah bermukim di Yogyakarya karena menempuh pendidikan tinggi di sana. Lahir dan dibesarkan di Sumenep. Banyak menulis puisi dan karyanya masuk dalam berbagai antologi.

Majas simile atau asosiasi digunakan Nurul Ilmi Elbana dalam puisinya, antara lain dalasm "Catatan Harian Angeline".

di rumah, gedung membentuk benteng seperti penjara Cinderella

memaku gerak dan pikir. Terkurung seribu keinginan oleh tegak

pekerjaan

sepi sunyi menempel di dinding dan jendela. ada suara menjadi ular

berbisa dan melilit kaki-kaki sukma.

Sementara rumah kawan-kawanku luas tak terbatas

jendela dan pintunya terbuka dan bercabang ke mana-mana (PL, 2017:76).

Majas terdapat pada baris bait di rumah, gedung membentuk benteng seperti penjara Cinderella, maknanya tentang seorang yang merasa terkekang atau terpenjara, bukan terpenjara karena tidak bisa pergi keluar rumah, melainkan tidak bebasnya berbicara, berkehendak, atau tentang rintangan jiwa menjadikan jiwa terasa sepi, berbeda dengan kondisi di tempat lain yang lebih leluasa.

Majas yang lebih banyak pada puisi Nurul adalah pesonifikasi. Pada pusi "Rencana Usai Penutupan Dolly" dia menulis, "wisma-wisma yang berdiri kukuh dengan angkuh / tak boleh lagi menghidupi mulut / dilarang menjadi jembatan penyambung hidup". Majas yang sama ditulis pada puisi "Labang Mesem": dan pintu itu akan membukakan ponconiti / yang lama terkunci oleh tangan matahari / kita masuki dengan dengan segala niat suci."

Personifikasi memang majas yang sangat populer digunakan oleh para penyair. Alam dan benda-benda mati diberi sifat seperti manusia yang dapat bertindak. "Apakah jarak mampu mencuci waktu? " tulis Nurul dalam puisi "Hari Ibu", seakan jarak itu dapat mencuci sebagaimana manusia. Ini dengan model yang ditampilkan dalam puisi "Catatan Harian Angeline":

hari esok bagiku hanyalah langit yang

terus meninggi

sedang waktu bergerak dengan merangkak

hari-hari berpindah nama penuh perintah dan sumpah serapah

oh, Ayah, baikkah kau di sana?

(PL, 2011:77).

Pada puisi "Bulan Pucat di Bantaran Rel Kereta" Nurul juga mengguratkan majas personifikasi terkait tema-tema pelacuran dalam beberapa puisinya, 
"warung-warung kecil di tepi rel kereta / tak jemu mengukur bayangan senja / mencatat tanpa cacat / siapa yang dating dan pulang". Tema dunia pelacuran pun ditulis dengan majas yang sama pada puisi "Sebuah Gang, Suatu Malam: Sarkem": malam kian mengibarkan asap rokok / dan kecut parfum / pesona rayuan untuk para lelaki yang berkeliaran / tawar menawar lalu naik ranjang”.

Terkait dunia para petani yang bersusah payah menyambung hidup, Nurul Ilmi Elbana juga melukiskannya melalui majas personifikasi dalam puisi "Nubuat Para Petani”.

kalau tidak,

angin gagah dari utara akan menyambar

seluruh arah menghilang jadi samar

benih-benih menuntunmu jadi pembunuh

bukan pahlawan yang diharapkan datang

(PL, 2017:80).

\section{Majas dalam Pusi Karya Nay Juireng Dyah Jatiningrat}

Karya puisi yang keembilan dari sepuluh perempuan penyair Madura adalah Nay Juireng Dyah Jatiningrat. Nay adalah perempuan yang lahir dan besar di Madura, pendidikan tingginya ditempuh di kota Malang. Meski ada beberapa puisi dalam antologi, ada satu puisi yang menggunakan majas simile atau asosiasi. Puisi itu adalah "Lelakiku". Melukiskan sosok manusia dengan perbandingan alam berupa pantai dan taman.

Aliflayyin tubuhmu lentur

Solah-olah pantai malam di malamku

Bisik-bisik nafasku membinarkanku

Menarik-narik mataku di suhu-suhu waktu

Lagi-lagi desah ombak

Keruh otakku

Bising tubuhku

Hingga jagat adalah tubuhmu cahaya mataku

Kau selalu di sini

Tidur dan mencari

Seperti luas taman bunga dengan lari-lari anginnya

(PL, 2017:82).

Pada kutipan di atas kata-kata "seolah-olah" dan "seperti" secara eksplisit digunakan oleh penyair untuk membentuk perbandingan secara persamaan. Seperti tertera pada judul, nama Aliflayyin pada baris awal dapat dikonotasikan dengan seorang, mungkin suami atau anak. Tentu dapat pula dikonotasikan sebagai simbol sesuatu.

\section{Majas dalam Puisi Karya Salama Elmie}

Salama Elmie merupakan penulis yang puisinya diletakkan di bagian akhir buku Perempuan Laut, termasuk urutan biografi yang bersangkutan di akhir buku. Meski tidak tertulis angka tahun kelahiran, kemungkinan besar editor sudah memperhitungkan penempatan ini. Dia lahir dan besar di Madura, tapi menempuh pendidikan tinggi di Yogyakarta.

Ada beberapa puisi Salama Ilmie yang menggunakan majas personifikasi, antara lain pada puisi "Hujan Malam Ini". 
riuh angin dan ketenangan awan

menenangkan hati dan membuat penat

adakah jamu yang lebih mujarab

dari seorang penyair tempo dulu

(PL, 2017:92).

Angin dan awan, sebagai bagian dari alam, diberi perilaku yang dapat menenangkan jiwa manusia. Ini juga berlaku pada gerimis yang terdapat pada puisi "Mengenang Setelah Kau Tiada":

aku tak perlu gerimis yang menghapus kesepianku

aku hanya ini menulis saat kehilangan

saat halaman rumah makin tak tenang (PL, 2017:93).

Langit dan angin juga dipersonifikasikan oleh penyair, mirip seperti pada puisi sebelumnya. Pada "Hujan Bulan September" Salama Ilmie menulis, "Ku melihat langit pekat berkelebat / Berdetak di jantungku / Ketika angin menghempas pelan / Sepelan aku memahami kehidupan".

Tampak bahwa secara maknawi puisi-puisi Salama Ilmie berbicara tentang masa lalu dan jarak. Masa lalu yang telah dilalui, termasuk orang-orang tercinta yang telah tiada. Jarak juga menjadi bagian penting dari puisi penyair ini. Ada kerinduan dan pengalaman yang muncul kembali ketika jarak dari kampung halaman semakin jauh. Suasana yang diabangun menjadi lebih terasa ketika dihadirkan suasana hujan dan sepi. Pas untuk mewakili rasa dalam pengembaraan diri sang penyair.

\section{SIMPULAN}

Puisi adalah seni bahasa yang mengambil bahan dari kehidupan nyata dan dituangkan secara imajinatif. Bahasa merupakan piranti yang mutlak digunakan oleh penyair. Bahasa yang digunakan tersebut diolah sedemikian rupa agar tercapai efek keindahan yang maksimal dalam bentuk puisi. Pada konteks inilah majas atau gaya bahasa dihadirkan oleh penyair. Penyair dalam memilih penggunaan kata atau bahasa, disadari atau tidak, pasti akan berhubungan dengan majas tertentu. Hal ini pula yang terjadi pada antologi puisi Perempuan Laut yang ditulis oleh sepuluh perempuan penyair Madura.

Sesuai dengan tujuan penelitian, penggunaan majas personifikasi dan simile/asosiasi ditemukan dalam sejumlah puisi dalam antologi Perempuan Laut. Majas personifikasi adalah gaya bahasa yang memberi sifat atau perilaku benda mati, barang, atau alam seperti sifat-sifat atau perilaku manusia. Sedangkan majas simile/asosiasi adalah gaya bahasa menunjukkan persamaan antara dua hal yang di tengah-tengahnya ditandai dengan penggunaan kata "seperti", "bagai", "sebagai", "bagaikan", "laksana", "menyerupai", "tak ubahnya", "bak", dan sejenisnya. Kedua jenis majas tersebut ditemukan pada puisi-puisi yang ditulis oleh sepuluh perempuan penyair Madura.

Penyair Weni Suryandari menggunakan majas personifikasi pada puisinya yang berjudul

"Perempuan Laut", "Pohon Perempuan", dan "Panen Air Mata". Majas simile digunakannya pada puisi "Pohon Perempuan", "Mawar Gugur", "Menjemput Bintang", dan "Rumah Lupa". Majas-majas tersebut umumnya dipergunakan oleh Weni Suryandari untuk mengangkat persoalan perempuan dengan nada sedih. 
Pada puisi-puisi karya Maftuhah Jakfar juga ditemukan penggunaan majas personifikasi dan simile. Puisi yang berjudul "Mikraj Cinta IV","Mikraj Cinta V", "Nur Ala Nur", dan "Rindu Ilalang I" menggunakan majas simile di dalamnya. Majas personifikasi digunakannya dalam puisi "Mikraj Cinta I" dan "Mikraj Cinta III". Majas-majas tersebut umumnya dipergunakan Maftuhah Jakfar dalam melukiskan spiritualisme terkait hubungan antara manusia dengan Tuhan, manusia dengan manusia, dan manusia dengan alam.

Pada puisi-puisi karya Nok Ir tidak banyak ditemukan majas yang menjadi fokus penelitian. Hanya ada sebuah puisi yang menggunakan majas personifikasi, yaitu yang berjudul "Selamat Malam Sang Penyair" (bagian III). Puisi-puisi Nok Ir umumnya melukiskan perjalanan hidup dari masa lampau beserta kenangan yang melekat.

"Ombak Hidup" adalah puisi Juwariyah Mawardy yang di dalamnya menggunakan majas personifikasi. Sedangkan puisi "Sajak dari Kampung" dan "Wajahmu adalah Pintu" terdapat majas simile di dalamya. Puisi-puisi Juwariyah Mawardy secara umum melukiskan jatuh bangunnya hubungan antarmanusia dengan berbagai cobaan, yang pada akhirnya harus dikembalikan kepada Tuhan sebagai pemilik kehidupan.

Majas personifikasi dijumpai dalam puisi karya Linda Autaharu yang berjudul "Tangga dan Gajah", "Selamat Pagi: Anakku", "Lelaki Berwajah Kemarin", dan "Tidurlah". Puisi-puisi Linda Autaharu banyak yang berbicara tentang hubungan ibu dan anak, serta sosok lelaki yang tampaknya terjadi keretakan hubungan.

Majas personifikasi dalam puisi Tika Suhartatik antara lain terdapat pada puisi "Pilihan Janji Bersama Waktu”, "Ada Tuhan Antara Kau dan Aku”, serta "Buku Puisi: Menyibak Dilema di Sebuah Negeri Tak Beratap." Di samping persoalan personal, puisi Tika Suhartatik banyak yang merupakan kritik terhadap dunia perpolitikan tanah air. Ada nuansa keprihatikan, namun di sisi lain ada tekad yang ingin tetap ditegakkan dalam kehidupan bernegara.

Benazir Nafilah menggunakan majas personifikasi pada puisi "Akhirnya" dan "Bertemu Puisi". Dia juga menggunakan simile pada puisi "Bertemu Puisi", "Kedua Mata Nabil, Sareyangku", "Telur Dadar", dan "Akhirnya”. Puisi-puisi Benazir banyak melukiskan kecintaannya pada puisi dikaitkan dengan anak, serta terjadinya permasalahan hubungan dengan pihak lain.

Pada puisi "Catatan Harian Angeline" karya Nurul Ilmi Elbana terdapat majas simile. Puisi tersebut juga menggunakan majas personifikasi di dalamnya. Majas personifikasi lainnya terdapat dalam puisi "Rencana Usai Penutupan Dolly", "Labang Mesem", "Hari Ibu", "Bulan Pucat di Bantaran Rel Kereta", "Sebuah Gang, Suatu Malam: Sarkem", serta "Nubuat Para Petani". Nurul Elmi Elbana pada puisi-puisinya banyak melukiskan masalah pelacuran serta kehidupan orang-orang kecil lainnya.

Nay Juireng Dyah Jatiningrat menggunakan majas simile pada puisi "Lelakiku". Sementara Salama Elmie menggunakan majas personifikasi pada puisi "Hujan Malam Ini", "Mengenang Setelah Kau Tiada", dan "Hujan Bulan September". Puisi-puisi Salama Ilmie berbicara tentang masa lalu dan jarak. Masa lalu yang telah dilalui, termasuk orang-orang tercinta yang telah tiada. Jarak juga menjadi bagian penting dari puisi penyair ini. Ada kerinduan dan pengalaman yang muncul kembali ketika jarak dari kampung halaman semakin jauh. 


\section{DAFTAR PUSTAKA}

Keraf, Gorys. 1986. Diksi dan Gaya Bahasa. Jakarta: Gremedia.

Kutha Ratna, Nyoman. 2016. Stilistika Kajian Puitika Bahasa, Sastra, dan Budaya. Yogyakarta: Pustaka Pelajar.

Moleong, Lexy, J. 2014. Metode Penelitian Kualitatif. Bandung: PT. Remaja Rosda Karya.

Nurhamidah, Siti. 2019. Gaya Bahasa pada Kumpulan Puisi Perahu Kertas karya Sapardi Djoko Damono dan Rancangan Pembelajaran di Sekolah Menengah Atas (SMA). Dalam

WWW//http//pdf/digilib.unila.ac.id. Diakses 29 Agustus 2019

Sayuti, Suminto A. 2008. Berkenalan dengan Puisi. Yogyakarta: Gama Media.

Sumardjo, Jakob \& Saini KM. Apresiasi Kesusastraan. Jakarta: Gramedia.

Suryandari, Weni, dkk. Perempuan Laut (PL). Antologi Puisi 10 Penyair Perempauan Madura. Sumenep:

Forum Bias.

Luxemburg, Jan van; Mieke Bal; , dan Willem G. Weststeijn. 1986. Pengantar Ilmu Sastra (Diindonesiakan Dick Hartoko). Jakarta: Gramedia.

Toolan, Michael J. 1990. The Stylistics of Fiction. London and New York: Routledge. 